\title{
The Psalms and the English Reformation
}

\section{RUTH AHNERT}

In the Parker Library at Corpus Christi College library sits a fourteenth-century manuscript containing two versions of the Psalter, copied in the same fine large hand. The first is translated into Middle English, the latter is rendered in Anglo-Norman. ${ }^{1}$ Despite its pre-Reformation origins, this manuscript is witness to the sixteenth-century controversy over the propriety of translating the Bible into the vernacular. The doublePsalter is presumed to have been procured from Norwich Priory by the library's founder, Archbishop Matthew Parker, a key figure behind the reformist project of Biblical translation. Parker was the driving force behind the Bishop's Bible of 1568 (himself translating Genesis, Exodus, the gospels of Matthew and Mark, all of Paul's epistles except for Romans and 1 Corinthians, and the epistle to the Hebrews); he produced a metrical paraphrase of the entire psalter, which he later published at the urging of friends; and he played an active part in the development of a liturgy in English. The creation of his library was directly connected to this project of translation: motivated by the need to find evidence for the existence of an ancient English-speaking Church independent of Rome, he became particularly keen to preserve materials relating to Anglo-Saxon and medieval England. ${ }^{2}$ In John Foxe's words, Parker collected books to show that 'religion presently ... is no new reformation of thinges lately begonne, which were not before, but rather a reduction of the Church to the Pristine state of olde conformitie.' In this context, the fourteenth-century double-Psalter acts as a piece of evidence that the programme of biblical translation was not an aberration, but rather a practice with a long history.

Despite Parker's best efforts, however, the Reformation is now commonly viewed as a moment of juncture and revolution. What are we, then, to make of Parker's library, and his double Psalter in particular? The contention of this special issue is that psalm translation is an important witness to the religious, political and literary developments that took place in the sixteenth century; and that these developments both complicate and contradict our assumptions about the drives underlying the English Reformation. Parker is a figure that is mentioned in several of the following articles: in

\footnotetext{
${ }^{1}$ Corpus Christi College Library (CCC), University of Cambridge, MS 278, Psalter (Middle English and Anglo-Norman), f. 1 $^{\text {r }}$.

2 On Parker's library see Timothy Graham, 'Matthew Parker's manuscripts: an Elizabethan library and its use', in Elizabeth Leedham-Green and Teresa Webber (eds.), The Cambridge History of Libraries in Britain and Ireland, Volume 1: To 1640 (Cambridge: Cambridge University Press, 2006), 322-41; and R. I. Page, Matthew Parker and his Books: Sandars lectures in bibliography delivered on 14, 16, and 18 May 1990 at the University of Cambridge (Kalamazoo, MI: Medieval Institute Publications 1993).

${ }^{3}$ John Foxe (ed.), The Gospels of the fower Euangelistes translated in the olde Saxons tyme out of Latin into the vulgare toung of the Saxons, newly collected out of auncient monumentes of the sayd Saxons, and now published for testimonie of the same (London: John Day, 1571), sig. I.i.ir.
} 
his hands the psalms are both a tool both for driving change, and evidence for his narrative of historical continuity.

The cultural significance of the psalms in early modern England is, by now, widely recognized. The earliest intervention in the field was Rivkah Zim's 1987 monograph, English Metrical Psalms: Poetry as Praise and Prayer, 1535-1601, which charts the emergence and popularization of 'metrical psalms', a genre that includes paraphrases of psalms in English, printed as poems or set to music. Their popularity is attested to both by the number of people who undertook such paraphrases (Thomas Wyatt, Henry Howard, the Earl of Surrey, Thomas Smith, Thomas Sternhold, Phillip Sidney and his sister Mary, amongst others) and their commercial success. ${ }^{4}$ Since Zim's study, a number of books have demonstrated that the significance of the Book of Psalms in the early modern period reaches far beyond their translation into verse. Hannibal Hamlin's Psalm Culture and Early Modern Literature shows that their impact was broadly felt through citation and allusion in religious and political polemic, sermons, secular poems, plays, and prose fiction. Both Hamlin and Zim's studies agree that the appeal of the psalms derives, ultimately, from the fact they are not the word of God, but a model for how we should speak to God. They express the whole gamut of human emotion, providing a way of praising God in joy ('O sing unto the Lord a new song, for he hath done marvellous things', Ps. 98.1), expressing sorrow and confusion ('My God, my God, look upon me, why hast thou forsaken me', Ps. 22.1), or the desire for vengeance ('for thou smitest all mine enemies upon the cheekbone; thou hast broken the teeth of the ungodly', Ps. 3.7). ${ }^{5}$ The range of emotions means that the psalms can seem to speak to a reader's specific circumstances, which makes them a valuable source for appropriation, whether that be for political, religious, intellectual, or personal agendas.

Other studies have concentrated on more specific areas of psalm culture. Claire Costley King'oo has argued that, amongst the psalms, the most influential were the seven Penitential Psalms, which remained a touchstone for devotion from the fourteenth to the beginning of the seventeenth century. ${ }^{6}$ Beth Quitslund has written the definitive study of the The Whole Booke of Psalmes (sometimes anachronistically known as 'Sternhold and Hopkins'), a collection of metrical psalms set to music which not only became central to the development of Protestant worship in England, but also remained one of the bestselling publications of the Tudor age; her forthcoming edition of this book, produced in collaboration with Nicholas Temperley, will also allow readers to hear the contemporary settings of these verses to music. ${ }^{7}$ Timothy Duguid's recent study provides a musical and

\footnotetext{
${ }^{4}$ Rivkah Zim, English Metrical Psalms: Poetry as Praise and Prayer, 1535-1601 (Cambridge: Cambridge University Press, 1987; reissued 2011).

${ }^{5}$ Psalm quotations, unless otherwise specified, are Miles Coverdale's, from Brian Cummings (ed.), The Book of Common Prayer: The Texts of 1549, 1559, and 1662 (Oxford: Oxford University Press, 2011), hereafter BCP. Like other Protestant Bibles after 1539, this volume follows the traditional Hebrew numeration of the Masoretic text rather than the Greek Septuagint numbering that was adopted in the Latin Vulgate Bible.

${ }^{6}$ Claire Costley King'oo, Miserere Mei: The Penitential Psalms in Late Medieval and Early Modern England (Notre Dame, Ind.: University of Notre Dame Press, 2012).

${ }^{7}$ Beth Quitslund, The Reformation in Rhyme: Sternhold, Hopkins and the English Metrical Psalter, $1547-$ 1603 (Farnham: Ashgate, 2008); see also Quitslund, 'The Psalm Book', in Andy Kesson and
} 
theological analysis of the development of English and Scotland. ${ }^{8}$ And, Linda Phyllis Austern, Kari Boyd McBride, and David Orvis have edited a collection of essays that explore the use, interpretation, development, translation, and influence of the psalms in the Atlantic world, 1400-1800 - showing how the vigour of psalm culture in early modern England spread across the English-speaking world. ${ }^{9}$ Taken together, these studies show that the diverse functions that the psalms served as a mainstay of religious devotion in the Catholic and Protestant churches; a model for Christian worship and communal singing; an outlet for political and religious dissent; an object of literary inspiration and innovation; and an item of cultural exchange.

The function of this current volume is to turn the focus back onto the period that produced these cultural artifacts, and to examine how the use of the psalms might help to nuance our understanding of large-scale cultural change in the sixteenth century. The Tudor era was one of intense religious, political and intellectual upheaval: the English Reformation was heralded, intellectually, by the popularization of humanistic thought and education; and the five separate Tudor monarchs who reigned during this century imposed a range of religious positions on their subjects, enforcing orthodoxy with the threat of imprisonment and execution, which was all too often carried out. The period is often characterized as one of crisis, on the one hand, and innovation, on the other. The very term 'reformation' implies a break with the immediate past, and the restoration or rebirth of an original form or previous (better) condition. ${ }^{10}$ The place of biblical translation within this movement seems to emphasize the narrative of cultural rupture. On the one hand there is the backward-looking, Latinate, hierarchical tradition of the Catholic church; on the other is the forward-looking project of vernacularization, driven by the reformists, who believed that ordinary men and women should have access to a version of scripture that they could read and interpret for themselves. This 'chiaroscuro of negative and positive positions', ${ }^{11}$ as James Simpson puts it, invites us to infer a further binary opposition: to interpret this moment of doctrinal division as a major cultural moment, one that might be regarded as having brought about the kind of paradigm shift that distinguishes the medieval world from the Renaissance.

However, this narrative, and the labels of 'medieval' and 'Renaissance', have been problematized in a number of important studies over the last couple of decades, which seem to bring us to the difficult conclusion that contemporary witnesses at once affirm and deny the notion of historical schism. ${ }^{12}$ There has been a long-held desire to pin the

Emma Smith (eds.), The Elizabethan Top Ten: Defining Print Popularity in Early Modern England (Franham: Ashgate, 2013), pp. 203-12.

${ }^{8}$ Timothy Duguid, Metrical Psalmody in Print and Practice: English 'Singing Psalms' and Scottish 'Psalm Buiks', c. 1547-1640 (Farnham: Ashgate, 2014).

${ }^{9}$ Linda Phyllis Austern, Kari Boyd McBride, and David Orvis (eds.), Psalms in the Early Modern World (Farnham: Ashgate, 2011).

${ }^{10}$ OED, $v^{1}$, 2.b.

${ }^{11}$ James Simpson, Burning to Read: English Fundamentalism and its Reformation Opponents (Cambridge, Mass.; London: Belknapp Press, 2007), 25.

${ }^{12}$ See for example, William Caferro, Contesting the Renaissance (Chichester: Wiley-Blackwell, 2011); James Simpson, Reform and Cultural Revolution, Oxford English Literary History Vol. 2: 1350-1547 (Oxford: Oxford University Press, 2002); and Brian Cummings and James Simpson (eds.), Cultural Reformations: Medieval and Renaissance in Literary History, Oxford Twenty-First Century 
moment of rupture at the moment Luther nailed his Ninety-Five Theses to the church door of All Saint's Church in Wittenburg in 1517, but in reality there had been calls to reform the Catholic Church since at least the twelfth century. The period now described as the Reformation, of course, was different from those previous movements. It was lasting and far reaching, in England changing forever the national form of religion; but it was also a bloody movement that turned families and neighbours against one-another, causing people to die for their beliefs, and others to kill. And crucially, the reformation of religious practice in England was drawn-out by successive regime changes and warring factions. At the same time, Brian Cummings is right when he describes the Reformation as a 'ragged shorthand for the domino of personal, communal and national transformations which it provoked'. ${ }^{13}$ Rather than speaking about a singular Reformation, the story of the vernacularization of the psalms in England suggests that it might in fact be more helpful to think of two separate movements, one coming from above, and another from below, culminating some decades later in the religious compromise that constituted the Elizabethan settlement.

This introduction seeks to provide a framework for the articles that follow. The nine contributions are grouped into four themes: voice (on translation, appropriation, and congregational song); politics (works by prisoners, and royal propaganda); penitence (the appropriation of the Penitential Psalms in world where they no longer possessed any sacramental or liturgical justification); and innovation (the literary and metrical innovations occasioned by psalm translation). By providing an overview of the way the psalms were translated, appropriated, marketed, read, sung, annotated, and embellished during the sixteenth century, this introduction outlines the overarching discourses and struggles that underlay these case studies. It contends that the Book of Psalms presented, in the broadest sense, an opportunity to negotiate the concept of tradition and authority: in different contexts, their role in devotion, literature, and music simultaneously argues for a narrative of continuity and of schism. By holding these positions in tension this volume offers a nuanced understanding of the ambiguous and contradictory ways that reformation was manifested in Tudor society, troubling not only the dichotomies between medieval and Renaissance, Latinate and vernacular, Catholic and Protestant, but also between sacred and secular.

\section{Reformation from above and below}

Like Lutheranism itself, the first full translation of the Bible into modern English came from the continent. Miles Coverdale printed his Bible from exile in Antwerp in 1535. As it was first conceived, it was an illicit, grass-roots form of activism: Bible translation was strongly associated with religious dissidence. This was due, in part, to recent history. One of Lollardy's principal challenges to orthodoxy had been its project of scriptural translation, which was subsequently outlawed by Bishop Arundel's Constitutions in

Approaches to Literature (Oxford: Oxford University Press, 2010).

${ }^{13}$ Cummings, $B C P$, xiii. 
1409. ${ }^{14}$ When Coverdale printed his Bible, the 1530 royal proclamation banning biblical translations was still in place. ${ }^{15}$ However, 1535 appears to have been a turning point: on the introduction of his Bible to England, it was met with approval and led to the formal commission to revise it as Henry's famous Great Bible, which was directed by a 1538 Injunction to be placed in all churches. However, this was not the radical shift in policy that it first appears. It is true that in the preceding years, Henry had finally broken with Rome (1534) over Pope Clement VII's refusal to grant him an annulment of his marriage to Catherine of Aragon. But the Reformation that Henry imposed on the church in England steered what George Bernard has described as a religious 'middle way' between Catholicism and Lutheranism. ${ }^{16}$ For the remainder of the Henrician reign, Catholics and evangelicals were both regarded as enemies of the state. This is perhaps best illustrated by the executions of the three Catholics (Thomas Abell, Richard Featherstone and Edward Powell), and three evangelicals (Robert Barnes, Thomas Gerard, and William Jerome) on the same day, 30 July 1540. Coverdale did not long feel it safe to remain in England, and by 1540 had returned to the continent. In this context, Henry's authorised Bible acted as a pragmatic attempt to wrest power from the evangelical community and their unauthorised, and often controversial, translations.

This policy is clearly illustrated by the famous woodcut on the title page of the Great Bible (Figure 1). The woodcut's stratified composition has Henry sitting at the apex handing down his Bible to Thomas Cranmer, on the left, and Thomas Cromwell, on the right. In the middle register Cranmer distributes the volume to the clergy; and, in the bottom register, the newly Englished Bible forms the basis of the priest's exhortations to his congregation. This is a representation of Reformation from above: Henry is thus the distributor of God's word on earth, and everyone gives thanks to him proclaiming 'VIVAT REX', and 'GOD SAVE THE KYNGE' - everyone, that is, except for the imprisoned figures in the bottom right-hand corner of the title page. This is an authoritarian message: whilst ostensibly celebrating the magnanimity and power of the monarch, it also provides the English people with a warning that only authorised forms of speech and writing are permitted. Dissident elements, such as those who challenged the doctrine of the church in England through their "perverse ${ }^{, 17}$ translations of the Bible, would be silenced and contained within the prison. This, however, was propaganda. Although the threat of imprisonment was often effected, the production of unauthorised translations was not stemmed. Ironically one of the most popular genres of literature to be produced by prisoners in Henry VII's period was a specific form of Bible translation: the metrical psalm.

\footnotetext{
${ }^{14}$ On the Lollard project of vernacularization, see Rita Copeland, Pedagogy, Intellectuals, and Dissent in the Later Middle Ages: Lollardy and Ideas of Learning (Cambridge: Cambridge University Press, 2001); and David Daniell, The Bible in English (New Haven: Yale University Press, 2003), chapter 5.

${ }^{15}$ Paul L. Hughes and James F. Larkin (eds.), Tudor Royal Proclamations, vol 1. The Early Tudors, 1485-1553 (New Haven: Yale University Press, 1964), 196-7.

${ }^{16}$ George Bernard, The King's Reformation: Henry VIII and the Remaking of the English Church (New Haven: Yale University Press, 2005), 282 and passim.

17 A. Luder et al (eds.), Statutes of the Realm, 34 Henry VIII, vol. III (Records Commission: London, 1817), 894.
} 
It is here we see the conflicting drive of Reformation, from below - in this case, from the prison. A growing body of secondary literature has observed the cultural significance of writings by early modern prisoners. ${ }^{18}$ Anne Askew is a key example of prisoners resorting to the psalms. Martyred on 16 July 1546, Askew is most famous for her account of her interrogation, or 'examinations', which were edited by John Bale and published in two volumes in 1546 and 1547. At the end of The first examinacyon we also find her metrical translation of Psalm 54: 'Loo, faythlesse men, against me ryse,/ And for thy sake, my deathe practyse'. ${ }^{19}$ Through her translation, Askew revoices the lament of the psalmist and thereby casts her interrogators as the 'faythlesse men'. Many other prisoners found sentiments in the psalms that expressed their anguish. In his contribution to this volume, James Simpson discusses how the psalms were also taken up by a number of, what he argues to be, 'evangelical or evangelical-leaning' courtiers during their imprisonments, including George Blage, Henry Howard Earl of Surrey (both imprisoned and executed during Henry's reign), Sir Thomas Smith (imprisoned 15491550), Robert and John Dudley the Younger (incarcerated at the accession of Mary I until autumn 1554); Sir Thomas Wyatt's Penitential Psalms are also often associated with his 1541 incarceration, although recently critics have tended to agree they were, more likely, penned just after his release (see also Hamlin's and William Rossiter's articles). ${ }^{20}$ Their use of the psalms, however, was oblique. They selected verses for paraphrase that spoke to their own experiences of persecution, betrayal, and resentment, but the act of paraphrase afforded them a powerful deniability. ${ }^{21}$

By contrast, in the hands of the Protestant martyrs of Mary I's reign, the psalms were used explicitly as a source of comfort in a time of persecution. John Hooper wrote a commentary on selected psalms (22, 62, 71 and 76) during his incarceration, which was published in 1580. Glossing Psalm 23.2 - 'He shall feede me in pleasant pastures, and he shall leade me by the riuers side' - he writes:

Let euery man and woman therefore examine their owne conscience, without flattering of them selues, and they shal find that the most part of this realme of England in the time of our holy and blessed king Edward the sixt, were fed with this holy foode of Gods worde, or else might haue bene fed with it. For it was off ered and sent vnto them, as well by most godly statutes and lawes of

\footnotetext{
18 Prison Writings in Early Modern England, ed. William H. Sherman and William J. Sheils as a special number of Huntington Library Quarterly, 72:2 (2009); Ruth Ahnert, The Rise of Prison Literature in the Sixteenth Century (Cambridge, Cambridge University Press, 2013); and Rivkah Zim, The Consolations of Writing: Literary Strategies of Resistance from Boethius to Primo Levi (Princeton: Princeton University Press, 2014), 80-103, 124-141.

${ }^{19}$ Elaine V. Beilin (ed.), The Examinations of Anne Askew (New York; Oxford: Oxford University Press, 1996), 72.

${ }^{20}$ Cf. Ahnert, The Rise of Prison Literature, 59-73; and Zim, English Metrical Psalms, 80-111.

${ }^{21}$ On the deniability afforded by psalm paraphrase, see Stephen Greenblatt, Renaissance SelfFashioning: From More to Shakespeare (Chicago, IL: University of Chicago Press, 1980; reprinted 2005), 121; and Brian Cummings, The Literary Culture of the Reformation: Grammar and Grace (Oxford: Oxford University Press, 2002), 224.
} 
Parleament, as by many Noble men, and virtuous learned Preachers. ${ }^{22}$

There is nothing obscure about the meaning of this paraphrase. By equating Edward VI's reign with the pleasant pastures of this famous psalm, Hooper makes it clear that, for the Protestant community, the current reign constitutes 'the vallie and shadowe of death'. Similarly, the martyr John Bradford's prose paraphrase and commentary on the psalms makes a direct comparison between the persecuted Jewish nation and Protestant martyrs. Quoting the passage on how the heathens polluted the Temple in Jerusalem, Bradford extrapolates:

even so now verie manye heathen and lymmes of Antichrist though outwardlie they profess Christ are come in to thyne enheritance and church which thow hast with us in this Realme of England: and have defyled thy hoolie temple that is the soules and bodies of manye which have professed the in whom as in thy temple thow shuldest dwell. ${ }^{23}$

In case his meaning is not entirely clear, Bradford continues by explaining that the means by which the temples (the 'soules and bodies' of believers) have been polluted is through the resort to 'idolatrical and antichristian service' in the 'Realme of England': specifically, the delivery of religious services in Latin, the devotion to saints, and the idolatrous worship of the Eucharist. And rather than leave the parallel between the persecuted Jews and contemporary martyrs implicit, he tallies up the deaths of 'Fryth, Barnes, Garritt, Jerome, Lambert, Lascelles, \&c., and . . ladie Jane [Grey]'. ${ }^{24}$ The implication is that they are the true church; the evidence is their very persecution. In the hands of prisoners and future martyrs, then, the psalms are the voice of the displaced, the outsider, and the revolutionary. But at the same time these biblical verses, historically associated with King David, provide the seal of authority, asserting the speaker's righteousness in God's eyes, and, by implication, the condemnation of their oppressors.

For the same reason, martyrs recited or sang psalms at their executions. According to John Foxe's famous martyrology, Actes and Monuments of these latter and perillous days, when John Rogers was brought to Smithfield to be burned, he spoke 'the Psalme Miserere by the way, all the people wonderfully reioysing at hys constancy, with great prayses and thankes to God for the same'. ${ }^{25}$ The Psalm Miserere (Psalm 51) is one of the seven Penitential Psalms, beginning 'Have mercy upon me, O God, after thy great goodness', and became heavily associated with Protestant martyrs due to the frequency with which it was spoken at their executions. ${ }^{26}$ This may explain why, despite ostensibly

\footnotetext{
22 John Hooper, Certeine comfortable expositions of the constant martyr of Christ, M. Iohn Hooper, Bishop of Glocester and Worcester written in the time of his tribulation and imprisonment, vpon the XXIII. LXII.

LXXIII. and LXXVII. Psalmes of the prophet Dauid (London: Henrie Middleton, 1580; STC 13743), sig. C.1 ${ }^{v}$. The rest of this paragraph draws heavily on my work in Ahnert, The Rise of Prison Literature, 59-61.

${ }^{23}$ Emmanuel College Library MS 261, fol. 174r.

24 Ibid.

${ }^{25}$ John Foxe, The Unabridged Acts and Monuments Online or TAMO (1570 edition) (HRI Online Publications, Sheffield, 2011), 1703: < http//www.johnfoxe.org> (Accessed August 2014).

${ }^{26}$ Danielle Clarke, The Politics of Early Modern Women's Writing (Abingdon: Longman, 2001), 131
} 
being executed for treason, Lady Jane Grey's death was appropriated for the Protestant cause; she spoke Psalm 51 in English before being beheaded. This psalm had long been associated with death, spoken as one of the seven Penitential Psalms by those on their deathbeds, and at funerals as intercessions for the souls of the departed, as part of the sacrament of penance in the Catholic church. However, following intense scrutiny by evangelical reformers, the sacrament of penance and prayers for the dead 'were dismissed (along with the entire devotional structure relating to Purgatory and good works) as superstitious rites. From the perspective of emerging Protestantism, therefore, the Penitential Psalms no longer possessed any sacramental or liturgical justification'. ${ }^{27}$ Yet, remarkably - as Clare Costley King'oo's extensive work on the Penitential Psalms has shown - they not only survived, but thrived. What made Psalm 51 a particularly attractive final prayer for Protestants was precisely its affirmation of their theological stance on penance and repentance. King'oo's work shows that Luther's commentary on the Penitential Psalms formed a crucial attempt to redefine both the meaning and practice of penance: 'disparaging the ecclesiastical sacrament of penance as an attempt to earn God's redemption, Luther argued that true repentance involved simply receiving the free gift of God's grace'. ${ }^{28}$ Psalm 51.16 provides a neat summary of that argument: 'For thou desirest no sacrifice, else would I give it thee: but thou delightest not in burntofferings'. However, this is not merely a statement of the meaningless of good works; it invites the listener also to consider the process through which the speaker of the psalmist's words would themselves become burnt offerings at the stake. The recitation of the psalm in this context, then, is a twofold form of defiance in the face of death: it is a restatement of the beliefs that put them there, and an assertion of the meaningless of their deaths. The psalms become part of performance of devotion that subverts the moment of execution, which, Michel Foucault famously argued, was designed to be a demonstration of the state's power. ${ }^{29}$ Instead it invites sympathy, awe, and even celebration in the martyr's fortitude, as we see in the case of Rogers: 'all the people wonderfully reioysing at hys constancy'. ${ }^{30}$

In the hands of prisoners, and men and women going to their deaths, the psalms tell a story of reformation from below, carried out by the persecuted and exiled. However, at the same time, the psalms remained a crucial expression of authorized religion through their place at the centre of liturgy; and it was through the revision and reshaping of the liturgy that another form of reformation was imposed from above. The scholarship on this area is rich and complex with important contributions from Eamon Duffy, Judith Maltby, Kenneth Fincham, Nicholas Tyacke and Brian Cummings,

\footnotetext{
${ }_{27}$ Clare Costley King'oo 'Rightful Penitence and the Publication of Wyatt's Certayne Psalmes', in Austern, McBride and Orvis (eds.), Psalms in the Early Modern World, 155-74 (159).

28 Ibid.

${ }^{29}$ Michel Foucault, Discipline and Punish: The Invention of the Prison, tr. Alan Sheridan (Harmondsworth: Penguin Books, 1979). On the failure of this thesis to account for martyrdom, see Thomas S. Freeman, "Imitatio Christi with a Vengeance": The Politicisation of Martyrdom in Early Modern England', in Freeman and Thomas F. Mayer (eds.), Martyrs and Martyrdom in England, 1400-1700 (Woodbridge, Boydell and Brewer, 2007), 35-69.

${ }^{30}$ Foxe, TAMO, 1703.
} 
amongst many others. ${ }^{31}$ The form and content of the liturgy in sixteenth-century England, and the psalms' place therein, can be seen as a thermometer of religious change. In its direct wake, it was it was difficult to foresee the impact that the break with Rome in 1534 would have on the practice of faith in England. Despite Cranmer's attempts to draw up a reformed liturgy that would be acceptable to the king, little progress was made except for a few concessions. In the 1535 'King's Primer' are printed English versions of Te Deum and the Canticles. In 1538 an injunction was passed that that the Creed, Lord's Prayer and Ten Commandments were to be recited in English in turn. And in 1544 a Litany was published for an English service to be used in processions throughout the province of Canterbury. For the most part, Duffy's statement that 'liturgy, ritual, and traditional religious forms and imagery remained central to lay devotion into the 1540s and beyond' is true. ${ }^{32}$ This changed, however, with the 1549 Act of Uniformity, which established The Book of Common Prayer (hereafter BCP) as the sole legal form of worship in England.

Cummings has argued in his recent edition that the BCP was an engine of change, 'imposed on congregations and causing riots through its perverse assumption of doctrinal oddity and destruction of old ways of experiencing the divine'. In reality, the sources for the first edition of the BCP were often taken directly from Latin liturgical tradition, and so in many ways this was not a dramatic departure; but, as Cummings points out, 'every omission and alteration from these sources, including the use of vernacular at all, was noticed by its original users, and felt to be a disturbance of the old ritual'. ${ }^{33}$ The main changes were the vernacularization of prayers and scripture; the removal of the elevation of the host during Mass; the removal of references to Purgatory and prayers for the deceased in the Office of the Dead; and the absence of Saints', and feast days. What is interesting is that the psalms remained untouched by these changes. They were not formally a part of the BCP until 1662, although the psalms' use was intrinsic to monthly cycles of devotion, as laid out in 'An ordre for Mattyns dayly through the yere'. This readiness to allow people to refer to their own Psalters (despite the fact that, from 1552 complimentary imprints were issued by the same printer of BCP and Psalter together), gave the sense that the Psalter remained untainted by this new order for religious services. Indeed, Cranmer's plan for the full recitation of all the psalms each month owes much to pre-Reformation liturgical patterns, in which all the psalms were recited in a single week; a pattern which had its origins with St Gregory. ${ }^{34}$ In this way the psalms formed an important point of continuity with the Catholic past during the Protestant reign of Edward VI.

\footnotetext{
31 Eamon Duffy, The Stripping of the Altars: Traditional Religion in England, c.1400-c.1580, second edition (New Haven: Yale University Press, 2005); Judith Maltby, Prayer Book and People in Elizabethan and Early Stuart England, Cambridge Studies in Early Modern British History (Cambridge: Cambridge University Press, 1998); Kenneth Fincham and Nicholas Tyacke, Altars Restored: The Changing Face of English Religious Worship, 1547-c.1700 (Oxford: Oxford University Press, 2007); and Cummings, BCP, Introduction.

32 See Duffy, The Stripping of the Altars, 5.

33 Cummings, $B C P$, xvii.

${ }^{34}$ Cummings, BCP, 784.
} 
Perhaps the most revealing facet of the BCP - and, crucially, what it can tell us about the direction from which reformation was being imposed - can be traced, not in its contents, but in its reception Despite violent rebellions against the 1549 BCP, resulting in 4,000 deaths in the southwest, the more radical elements of the Protestant church thought the new liturgy was not nearly reformed enough. Although their agitations resulted in the 1552 editions, its effect was limited due to Edward's death and the accession of his Catholic sister. But while the English journey towards reformation was temporarily reversed within England, it continued apace in the exile community on the continent. The irony is that by removing the most radical figures from their own country, the development of reformed worship was accelerated. And the place of the psalms in this process was central in a way that it had not been in England. As Nicholas Temperley's contribution to this volume describes in greater depth, during the Edwardian reign, and in parallel with the publication of the BCP, courtiers like Thomas Sternhold had begun to set psalms and other religious texts to music for performance before the king. The immense popularity of Sternhold's posthumously published metrical psalms, however, do not seem to have penetrated the Edwardian church; at least, there are no records of them being sung in a scared context. However, as Quitslund has observed, 'the metrical psalms of Sternhold and [John] Hopkins themselves changed profoundly and permanently as they traveled from the court to the congregations of exiles abroad'. ${ }^{35}$ In these diaspora communities, and in Geneva especially, the singing of psalms became a defining feature of communal worship. What we see in Geneva is the coming together of a set of music-ready translations and the existing continental practice of using psalms as congregational song, a practice that seems to have originated with the German Reformation, but spread quickly into Switzerland, France and beyond. When Elizabeth I succeeded her sister in 1558, the corpus of metrical psalms, and the practice of congregational singing, traveled back to England together. By 1562 John Day had published The Whole Booke of Psalmes, which 'reshaped the inheritance of the Marian exiles into a book of songs and prayers designed for the conditions of the new Elizabethan Church ${ }^{36}$ This publication, and its use throughout England, represents the culmination of two reforming drives: it represents the radical Protestant practices propagated in spaces outside the English church - the secular space of the court and religious exile communities - being ultimately incorporated into top-down policies sanctioned by Elizabeth's councillors and the ecclesiastical authorities.

\section{$* * * *$}

\section{Private readers and the art of appropriation}

It is important to stress, however, that just because public worship enforced a certain form of devotion, that this did not systematically change people's private beliefs and devotional lives. In addition to the public riots against the $1549 \mathrm{BCP}$, people practiced silent, and therefore less dangerous, forms of resistance through their private devotions.

\footnotetext{
35 Quitslund, The Reformation in Rhyme, 6.

36 Ibid.
} 
Duffy's Marking the Hours charts the history of the Books of Hours, which outlined a pattern of daily devotions that arose from monastic guides, and contained a large selection of psalms including the Gradual Psalms and Penitential Psalms, as well as those found in the 'Little Hours' of the Virgin and the Office of the Dead. By the 1570s attempts to reappropriate the Book of Hours for a Protestant audience had largely failed, and it was widely regarded as a sign of Popish devotion. However, in the period between the Break with Rome and ultimate demise, its survival and use by successive generations shows the reluctance with which people gave up familiar rituals. We can trace from marginal annotations the way that people interacted with this Catholic devotional mainstay over the decades. Duffy's study shows that following a 1538 proclamation which demanded that all images of Thomas Becket should be destroyed, people largely acted obediently: the majority of surviving manuscripts show users blotted, scraped, and crossed out references both to St Thomas and the Pope. ${ }^{37}$ But, importantly, the book was left largely unmolested. It therefore provided a resort and comfort for those who adhered to their Catholicism, either privately or publicly. Thomas More famously annotated his prayer book (comprising a copy of a printed Book of Hours published in 1530, and a Latin Psalter, bound into one volume) during his imprisonment in 1535. The Book of Hours bears the thirty-seven lines of his 'Godly Meditation', copied over some eighteen consecutive pages; and the Psalter contains 143 Latin annotations between Psalms 3 and 106 (105, using the Vulgate numbering of this Psalter). The nature of these annotations invites us to see the psalms as a constant source of comfort and guidance in the months leading up to More's execution. Evidently made over a period of time, which can be seen by changing hand and ink in which they are made, he appears to have sought out psalms that spoke specifically to the topic of 'tribulation' - the topic at the heart of his most famous prison writing, A Dialogue of Comfort Against Tribulation. The annotations to his prayer book comprise four references to imprisonment; and the word 'tribulatio' occurs 27 times, three of which appear beside Penitential Psalms, 32 (31), 38 (37) and 102 (101). The annotation beside Psalm 38.11-18 (37.12-19) comments on a passage that describes how friends and neighbours have turned against the psalmist and spoken lies 'Ego autem tamquam surdus non audiebam: et sicut mutus non aperiens os suum. Et factus sum sicut homo non audiens: et non babens in ore suo redargutiones' ('As for me, I was like a deaf man and heard not: and as one that is dumb, who doth not open his mouth. I became even as a man, that heareth not: and in whose mouth are no reproofs'). Here More writes:

sic se debet habere uir mitis in tribulatione / et neque superbe loqui neque regerere male
dicta sed maledicentibus benedicere et libenter pati sive iusticiae causa si mernit sive dei causa si
non meruit
[a meek man ought to behave in this way during tribulation; he should neither
speak proudly himself nor retort to what is spoken wickedly, but should bless
those who speak evil of him and suffer willingly, either for justice' sake if he has

${ }^{37}$ Eamon Duffy, Marking the Hours: English People and Their Prayers, 1240-1570 (New Haven: Yale University Press, 2007), 151-2. 
deserved it or for God's sake he has deserved nothing]. ${ }^{38}$

The desire to read this annotation biographically is tempting, especially in light of More's famous silence on the reasons for his refusal to sign the oath to the Act of Supremacy. The annotation suggests that not only had he meditated on the significance of this verse, but that he had marked it out for future reading. This policy of (political) silence suggests how the psalms represented both a safe haven for Catholics, and a source of motivation for resistance. In More's marginal engagement with the Psalter, the words and actions of the psalmist and More begin to overlap and merge. On the one hand we can see that More seeks to make his attitude and actions conform to this biblical model, but on the other he is also appropriating the psalms for his own purposes.

The availability of the psalms both as private guidance and validation is apparent in the annotations of another famous prayer book: Henry VIII's Psalter, now held at the British Library as Royal MS 2 A XVI. This manuscript Psalter was copied and illuminated by Jean Mallard, an emigré from the court of the French king Francis I, in 1540 and presented to the English king. The volume is famous for the series of miniatures representing Henry VIII as the new David, which build on the tradition that the psalms represent an autobiographical collection of lyric songs composed by King David. In Mallard's hand the psalms are thus presented as a model for Reformation kingship, and Henry shows his acceptance of this concept through his annotations in this volume. His annotations mark out verses pertinent to kingship: 72.4 is annotated with the words 'officium regis' (the king's office); 'de rege' (concerning the king) appears beside 63.11; 'de regibus' (about kings) beside Psalm 21; and Psalm 20.9 is signalled as 'pro rege oratorio' (a prayer for the king). But he not only consults the psalms for advice, but also for assurance that God supports his actions: nota bene marks appear beside Psalms 11.6 and 41.11, verses which exult that God will uphold him (the psalmist) and direct fire and brimstone against his enemies. ${ }^{39}$ Such annotations follow the example of patristic exegesis, which advises Christians to read and speak the psalms as if the words are their own. The irony is that the psalms speak as well for the man oppressed by the king as for the king himself. In this irony we see the polyvalency of this biblical book: the psalms can be private comfort for More in his tribulation, spoken publicly by Protestants at their executions, or used as a tool of propaganda (as demonstrated by Micheline White's article on Katherine Parr's translations of John Fisher's Psalmi seu precationes). This polyvalence is rendered still more complex by the issue of translation, as Hamlin's contribution to this volume argues. If we take an example of Psalm 73 in the version printed in The Whole Booke of Psalmes, the words are at once Asaph's (to whom this is attributed in the Hebrew tradition), King David's (to whom all the psalms were usually attributed in the medieval and early modern periods, despite scholarly knowledge of their

\footnotetext{
${ }^{38}$ Louis L. Martz and Richard S. Sylvester (eds.), Thomas More's Prayer Book: A Facsimile Reproduction of the Annotated Pages (New Haven and London: Yale University Press, 1969), 75 for facsimile; 194 for transcription and translation. For analyses of More's annotations, see Duffy, Marking the Hours, chapter 7; and Zim, English Metrical Psalms, 82-5.

${ }^{39}$ For further discussion of Henry's Psalter, see John N. King, 'Henry VIII as David: The King's Image and Reformation Politics', in Peter C. Herman (ed.), Rethinking the Henrician Era: Essays on Early Tudor Texts and Contexts (Urbana: University of Illinois Press, 1994), 78-92.
} 
multiple authorship), Thomas Sternhold (who translated this psalm), and the congregation singing these words in church. Hamlin's contribution to this volume asks: 'Are God's, David's, the translator's, and the singer's voices blended in harmonious polyphony? Or can they sometimes clash or drown each other out?'

The acts of appropriation and re-voicing made the psalms not only a site of religious negotiation but also of literary innovation. The cultural impact of the Reformation was far reaching: its acknowledged links with humanistic thinkers and their writings mean we cannot separate religion from the intellectual and popular movements of the era. It has been argued that metrical paraphrase had a key influence on the generation of new verse forms in Tudor period. The obscurity of Hebrew verse, as Deirdre Serjeantson's article argues, gave carte blanche for invention when determining the form a paraphrase should take; and Michele Osherow provides one particular example of this in her contribution to the volume, which shows how the metaphors of needlework (רקמה rekmah) found in the Hebrew versions of the psalms inspired Mary Sidney to ingenuity both of form and language that mirrored the elaborately worked displays characteristic of women's embroidered scenes. As such, the example of the psalms provides justification for literary endeavours, suggesting the inherent worthiness of the metrical arrangement of words in biblical translation:

Iosephus sayth: and Philo wrighth,

That Dauid Metres made:

Quinquemetres: some trimetres,

by musikes tract and trade.

$[\ldots]$

And who that noth: and hath it waighde,

how Psalmes by Metre go:

Can blame no art: by rythme so layde, nor musike squard therto.

Thus Bernard swéete: in holy rede, Christes death reuolued in rythme:

So Ambrose sage: and worthy Bede, thought this no shame or cryme.

And what is verse: but rythme to name, in Lattine, Frenche, or Gréeke:

Our Englishe verse: I count the same, though all men hit not leke. ${ }^{40}$

These words derive from the dedication to the reader in The vvhole Psalter translated into English metre, which most critics now agree was written by Archbishop Parker in around 1556; it was published by John Day in 1567. This introduction, of course, began with

\footnotetext{
${ }^{40}$ Matthew Parker, The vvhole Psalter translated into English metre, which contayneth an bundreth and fifty Psalmes. The first quinquagene (London: John Day, 1567), sig. B. $\mathrm{i}^{\mathrm{r}-\mathrm{v}}$.
} 
Parker, examining and the way he sought to justify biblical translation by building a library that demonstrated the existence an ancient English-speaking Church independent of Rome. I will also give him the final word. His words in this dedication are related to his larger project of collection in that they too are a defense: in this case, pre-empting the attack against the activity of rendering biblical translation in metrical verse, a practice which to some seemed far too literary to honour God's word. This work is often seen as an inspiration for the Sidneys' psalm translations because Parker uses a different verse form for each psalm. ${ }^{41}$ Although elsewhere in this dedication he denounces 'lascivious' secular sonnets, ${ }^{42}$ he does not leave an aesthetic void; rather, his metrical experiments provide a model for literary and intellectual endeavour that is pleasing to God. As we can see in the passage above, they also reveal the humanist scholar within him, who finds an important justification for his practice in patristic sources. It is also an important predecessor to The Whole Booke of Psalmes and the practice of congregational singing: the published book features nine tunes by Thomas Tallis. This metrical paraphrase therefore expresses the concerns of the scholar, poet and the reformer compacted. Crucially, however, its innovations are a product of religio-political pressure, written as this married priest 'lurked secreatlye' in Cambridge during Mary's reign. ${ }^{43}$ For both Walker and Simpson, this pressure is the key marker of cultural revolution. Walker writes:

Like Simpson, I see these Renaissance innovations as the product of political pressure rather than of any 'liberating' possibilities created by the new learning and the new religion: unlike him I see them as consciously resisting rather than complying with that pressure. ${ }^{44}$

The disagreement attested to by Walker here is interesting. But this current volume suggests that they are both right: that cultural change is both a product of the institutional structures narrowing discursive space, and by those consciously resisting that pressure. Parker's paraphrase of the psalms is a case in point. When he wrote them in 1556 his was the voice of resistance, reform from below, but when these works were finally published eight years later by Day, Parker was part of the Protestant institution applying the pressure to conform.

\footnotetext{
${ }^{41}$ Hamlin, Psalm Culture, 10.

42 Parker, The vvhole Psalter. sig. B.iir ${ }^{\mathrm{r}}$.

${ }^{43}$ David J. Crankshaw, Alexandra Gillespie, 'Parker, Matthew (1504-1575)', Oxford Dictionary of

National Biography, Oxford University Press, 2004; online edn, May 2011:

<http://www.oxforddnb.com/view/article/21327> (Accessed February 2015).

${ }^{44}$ Greg Walker, Writing Under Tyranny: English Literature and the Henrician Reformation (Oxford:

Oxford University Press, 2005), 147.
} 